\title{
THE EFFECTIVENESS OF MONETARY POLICY TOWARDS STOCK INDEX CASE STUDI : JAKARTA ISLAMIC INDEX 2006-2014
}

\author{
Lak lak Nazhat El Hasanah ${ }^{1}$, Jihad Lubis Panjawa ${ }^{2}$ \\ ${ }^{1}$ Ilmu Ekonomi FE-UII \\ ${ }^{2}$ Ekonomi Pembangunan FEB-UMS \\ Correspondence E-mail: lala.aacp@gmail.com
}

Recieved: Desember 2015; Accepted: June 2016

\begin{abstract}
Abstact
Fluctuation in economy situation is an important indicator for investor decision making. The investor actions are base on the minimum risk while having maximum profit. One of it is observing the condition of macro variables within monetary policy. This research aims to analyze the impact of inflation, money supply, exchange rate, and birate towards stock of jakarta islamic Index. The type data used is times series periode 2006-2014. Multiple linier regression with chow test and dummy variable approach to compare and to know the behavior of each independent variables. The result shows partially that birate and exchange rate negatively impact Jakarta Islamic Index before global monetary crisis in 2008, while inflation and money supply not that significantly impact. After global monetary crisis in 2008, partially, birate variable and money supply significantly giving positive influence to Jakarta Islamic Index, while at same time exchange rate and inflation are not significantly influencial. Simultaneously, inflation, money supply, exchange rate, and birate influence Jakarta islamic Index.
\end{abstract}

Key Word : Monetary, JII (Jakarta Islamic Index), Inflation, BI rate, Rupiah Currency JEL Classification: E52

\section{Introduction}

There was serious financial turmoil in 2007 to 2009 . The subprime mortgage crisis was marked by the announcement of the bankruptcy of several financial institutions. The Dow Jones index was decreasing 18 percent within a week, which is the biggest declining in that period. The capital market of other developed countries also decresed, for example Nikkei index 225 and FTSE 100, significantly decrease 24 percent and 21 percent in the same periode. Beik et al. (2011). America is a superpower which has the strongest economic power in the world, and contribute about $20-30 \%$ of the turnover of the world economy. The United States economy has a GDP of US $\$ 13,1$ trillion, equivalent to $20 \%$ of world GDP in 2007 . US GDP rose in the third quarter by $4.9 \%$, even still have the purchasing power of consumers is high (90.6 IKK ), proved unable to sustain its economy from the credit crisis on the subprime market worth US \$ 1.8 trillion. The collapse of the supremacy of the United States threatened the recession, it is possible will impact on the economies of other countries in the world. (Sihono $\mathrm{T}, 2008)$

Global monetary crisis in 2007 did not only impact developed countries, but also developing countries, including Indonesia. In Indonesia capitalization, Composite Stock Price Index (IHSG) declined 54 percent in 2008, closed at level $1,355.4$, which was $2,627.3$ in the beginning of 2008 , at the same time the value of market capitalization fell and the stock volume extreamly declined. And the position of SUN until the end 


\section{Jurnal Ekonomi Pembangunan, 17 (1), Juni 2016, 100-107}

of December 2008, there were Rp.87,4 trillion, it's a decrease than September 2008 which had reached $\mathrm{Rp} 104,3$ trillion. While foreign position at SBI recorded Rp.8,4 trillion, it's extreamly declined position than August 2008 amounted to Rp.68,4. (Bank Indonesia, 2009)

Investors was faced difficult choices to decide where to put their investment which is able to be the alternative to solve the global crisis. Meanwhile, Islamic economicsdevelops and the existance of sharia capital market is hoped as a solution alternative. Jakarta Islamic Index (JII)s the only stock index in Indonesia which calculates the average price of stocks index for the type of business activities that meet the criteria of sharia. Historically, the existance of shariah capital market was started and introduced in 1997 through islamic mutual funds instruments. Owing to the cooperation between PT Bursa Efek Jakarta (BEJ) and PT Danareksa Investment Management (DIM) in July 2000, Jakarta Islamic Index (JII) was successfully formed. The membership of Jakarta Islamic consists of 30 stocks from all shariah stocks. Thetable below shows the development of JII, the fluctuation of price stock. In 2008, it significantly declined because of global monetary crisis, but after that it slowly grew. In 2009, the collective stock of JII increased up to 92.97 percent.

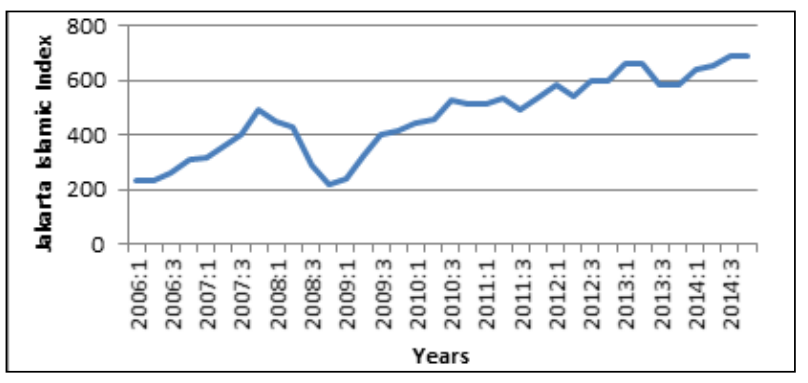

Figure 1. Development of Jakarta Islamic Index 20062014

Source: Bursa Efek Indonesia, 2015

The fluctuation of JII stock index is an interesting fenomenon to be observed, especially about how far macroeconomic and efectiveness pf monetary policy after after global crisis as represented by inflation, exchange rate, and money supply during 2006 untill 2014. Macroeconomic variables are expected to impact stock price in the future and become variable factor in investor's risk portfolio. Furthermore, it is important to learn the impact of macroeconomic variable in stock market, specifically Jakarta Islamic Index.

Each policy pursued by the government have to have targets and measures of success. It is important to measure or as a reference, whether the policy is effective or not. The effectiveness of monetary policy is, the extent to which the monetary policy pursued by the government (whatever its form), a positive impact on the economy and society. In some indkator economy that are typically used to assess the monetary policy is the inflation rate, interest rate/BI rate, the money supply and the exchange rate as well as the expectation/expectations of society towards monetary. Global financial crisis impact on the Indonesian economy, the monetary instrument is expected to come out of the global financial crisis.

Various empirical studies on the financial crisis has been a lot done, some of which examine the relationship between monetary intrument with stock index. Monetary instruments are macroeconomic variables are used to interpret and analyze the investors for making investment decisions and predicting financial trends or economic future. Investment can be done either in the money market and the capital market or placed as a credit to the people in need. Macroeconomic variables related to stock indices of which are inflation, interest rate and BI rate.

In general, inflation refers to the sustainability of mark-up, price increasing. It happens as the result of excess liquidity, money supply, and exchange rate which is influenced by Central Bank, as a tool of a state in controling the monetary policy. Moreover, these happen because of excess total demand which is affected by increasing number of liquidity in the market, 


\section{Jurnal Ekonomi Pembangunan, 17 (1), Juni 2016, 100-107}

hence the excess demand influence the price change. In other words, if inflation increases, then the company's revenue and cost also increase. However, if the incresing in production cost is higher than the income, therefore the profitability will decrease which impacts to the deviden received by shareholders (Pasaribu et al, 2013).

Theoretically, the interest rate and stock price have negative relationship with stock index (Tandelin,2010). Base on interest rate parity theory and adjustment portfolio theory, the change of foreign exchange rate will influence investor decision. The higher foreign interest rate compare to domestic interest rate results in capital outflow, because investors think it would be more profitable for them to invest abroad rather than inside the country. Regarding to that issue, the rise of foreign interest rate while domestic interest rate fall will negatively impact domestic capital market (Antonio et al, 2013)

In the reserach of Handayani (2007) shows that interest rate SBI, exchange rate in Dollar US and inflation affect the fluctuation of Indeks Harga Saham Gabungan (IHSG). Interest rate SBIhas a negative impact towards IHSG, meanwhile exchange rate of Dollar US and inflation has a positive influence.

Antonio et al. (2013) mentiones in his research that domestic macroeconomic variables influence exchange rate, interest rate, and inflation in Indonesia and Malaysia which also affect shariah capital market in both countries. These variables significantly influence capital market in each country.

Jonathan (2013) have done a research titled Analisa Pengaruh Inflasi, Suku Bunga dan Kurs Terhadap Volume Transaksi Pada Index LQ45, multiple regression linier is used as data analysis method. The research found partial interest rate of BI significantly influence stock trading volume and at the same time- inflation, BI interest rate, and Rupiah exchange influence stock trading volume.

Sani and Wahyudi (2013) in their research shows the result oftwo-way bivariat test between return JII and SBIS (syariah stock market), JII is able to describe macroeconomic variables movement which has two kind of content information that related to macroeconomic variables, such as exchange rate and interest rate.

Similarly to the result of Kristanti F.T et al (2013) research in Testing Of Macroeconomic Variables Jakarta Islamic Index (JII) with error correction model. Found that in the long term, inflation has negative impact towards JII and interest rates and the exchange rate positively affects JII.

Mulyani, (2014). in his research suggested that inflation positively affects the Jakarta Islamic Index (JII). In a study of inflation affect the Jakarta Islamic Index (JII) amounted to 95.525, any increase in inflation of $1 \%$ degan other variables in the conditions remain, the Jakarta Islamic Index (JII) will be increased by 95.525 units, it can happen because it is based on statistical data for the period years 2009 2011 average of $5.16 \%$ infalsi so that it can be categorized as tingakt low inflation, so investors reacted positively evidenced by its ability to continue to invest in the stock mark.

\section{Research Method}

The type of data used is times series. The object of this research is Jakarta Islamic Index (JII) from 2006 to 2012.Data used is triwulan series. The sources of this research are idx, Bank Indonesia, Kementrian Perdagangan, BPS dan related website. This research is using quantitative method with econometrics methodology. By using this methology, analysis tool that will be used is regression, a statistical tool which is designed to measure the direction and how influencial 


\section{Jurnal Ekonomi Pembangunan, 17 (1), Juni 2016, 100-107}

related variables to the dependent variables (Kerlinger, 1999). Regression used is multiple linier regression. The formula of multiple linier regression is:

$$
I I I_{t}=\beta_{0}+\beta_{1} B I R A T E_{t}+\beta_{2} \text { KURS }_{t}+\beta_{3} I N F_{t}+\beta_{4} J U B_{t}+\varepsilon_{t}
$$

which refers to:

B : parameter (konstanta dan JUB koefisien)

JII : Jakarta Islamic Index

BIRATE : Suku Bunga Bank Indonesia (Interest rate of $\mathrm{BI}$ )

KURS : Nilai Tukar Rupiah Terhadap

Dolar (Exchange rate toward Dollar)
INF : Inflation

: Jumlah Uang Beredar (Money supply)

Chow test with dummy is used to know the impact of each independent variables in multiple linier model before and after global monetary crisis.

$$
\begin{aligned}
I I I_{t}= & \beta_{0}+\beta_{1} \text { BIRATE }_{t}+\beta_{2} \text { KURS }_{t}+\beta_{3} I N F_{t}+\beta_{4} J U B_{t}+\beta_{5} d 1_{t}+\beta_{6} d 1 B I R A T E_{t}+ \\
& \beta_{7} d 1 \text { KURS }_{t}+\beta_{8} d 1 I N F_{t}+\beta_{9} d 1 J U B_{t}+\mathrm{v}_{t}
\end{aligned}
$$

which refers to: $d 1=$ dummyvariable, 1 for the data after fourth triwulan in 2008 (after global monetary crisis) and 0 for the data a year before the fourth triwulan (before global monetary crisis).

\section{Result and Discussion}

Capital markets have an important role to the state, one of which is to create facilities for industrial purposes and the entire entity to meet the supply and demand of capital markets. The existence of the Islamic capital market in Indonesia has contributed to the country's economy in various sectors. Jakarta Islamic Index, the index consist of 30 stocks which is able to acomodate shariah investment in Islam base on shariah law. In addition, this index consist of all stocks that fulfilling the investment criteria in shariah Islam. The stocks which is included in Shariah Index are the businesses who are not against islamic value. The grafic below shows the development of Jakarta Islamic Index.

Grafik Perkembangan JII Tahun 2006-2014

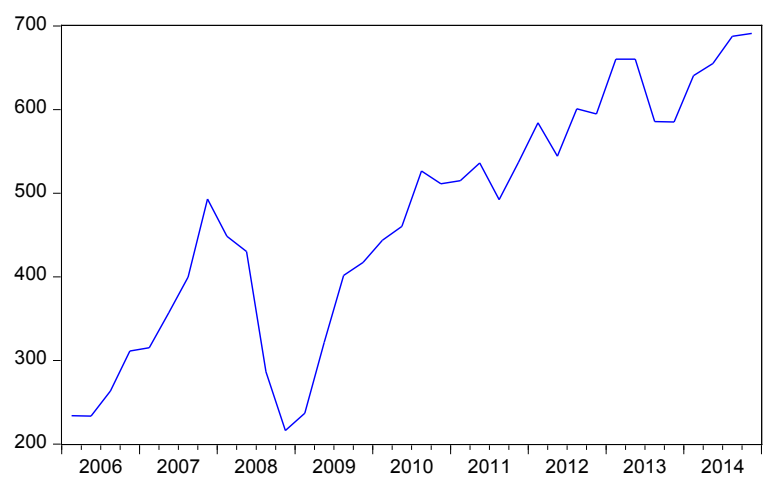

Figure 2. Development of JII 2006-2014

Base on the garfic above, the stock price of JII is fluctuative. In 2008, JII's stock was significantly decline. At the beginning of 2009, the stock of JII started to rise. 


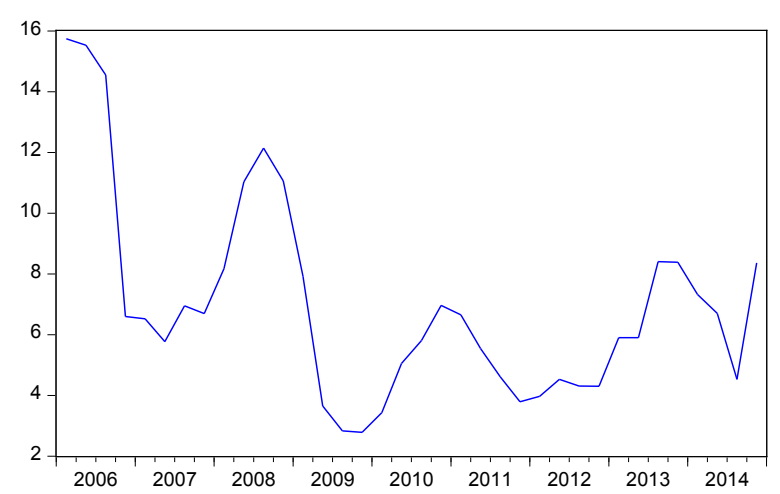

Figure 3. Development of Inflation 2016-2014

Source : Bank indonesia, 2015

Base on the grafic above which is about inflation, shows that inflation was fluctuative during 2006 until 2014. The highest inflation was in 2006, however after that it slowly declined. At the beginning of 2008 , the inflation started to grow until the end of 2008 .

Base on clasical hypothesis test, it shows there is no problem in the assumption, which means clasical hypothesis test is success.

Table 1. of Clasical Hypothesis Test

\begin{tabular}{lcc}
\hline \multicolumn{1}{c}{ Uji Asumsi Klasik } & Statistik & Prob. \\
\hline $\begin{array}{l}\text { Normalitas } \\
\text { (Jarque-Bera) }\end{array}$ & 0,0402 & 0,9801 \\
$\begin{array}{l}\text { Otokorelasi(Bruesch } \\
\text { Godfrey) }\end{array}$ & 5,5917 & 0,1333 \\
$\begin{array}{l}\text { Heteroskedastisitas } \\
\text { (White) }\end{array}$ & 9,0564 & 0,4321 \\
$\begin{array}{l}\text { Linieritas } \\
\text { (Ramsey Reset) }\end{array}$ & 0,1930 & 0,8258 \\
\hline
\end{tabular}

Source: Olah data Eviews8

Residual normality test shows that the score of prob.Jarque-Berais $0.9801>$ a $(0,10)$, it can be concluded that the residual distribution is normal. Base on Bruesch Godfrey test, shows the score ofprob.Chisquareis0.1333> a $(0,10)$, it can be concluded as no autocorrelation problem from the model, which means the value of variable in the past having no impact to the value of present variable or even future variable
Base on clasical hypothesis test for heteroskedastisitastest, shows that there is no heteroskedastisitasproblem in the model, due to the score of prob.Chisquare is $0.4321>\alpha(0,10)$, which means there are some residual variation in the model, as followed by changing in independent variable. In contrast, base on linearity test model, shows the model used is linier, owing to the prob. Fwhich is $0.8258>a(0,10)$.

Tabel 2. Goodness of Fit

\begin{tabular}{lcl}
\hline \multicolumn{1}{c}{ Goodness of Fit } & Statistik & Prob. \\
\hline Uji F & 52,4988 & 0,0000 \\
Rsquare & 0,9478 & \\
\hline
\end{tabular}

Base on simultaneity test, shows the existence of the model used, because the score of prob.Fis $0.0000<0,10$, it means that all the independent variables work together influence JII index, including inflation, exchange rate, BI rate, and money supply. However, the interpretation of $\mathrm{R}$ score is 0.9478 , which means the variation of JII variable can be explained by inflation, exchange rate, BI rate, and money supply which is 94,78 percent, the rest 5,22 percentis explained by other variables which is exclude in the model.

Table 3. of the Result of Regression

\begin{tabular}{lccc}
\hline \multicolumn{1}{c}{ Variable } & Coefficient & t-Statistic & Prob. \\
\hline C & 9961,2945 & 3,8393 & 0,0007 \\
D1 & $-13818,4411$ & $-5,0678$ & 0,0000 \\
BIRATE & $-74,7714$ & $-2,3792$ & 0,0250 \\
LOG (KURS) & $-779,8585$ & $-1,9942$ & 0,0567 \\
INF & 12,3473 & 1,4145 & 0,1691 \\
LOG (JUB) & $-134,3538$ & $-0,4884$ & 0,6294 \\
D1*BIRATE & 86,6611 & 2,2660 & 0,0320 \\
D1*LOG & & & \\
(KURS) & 371,4370 & 0,8996 & 0,3766 \\
D1*INF & $-14,3236$ & $-1,3284$ & 0,1956 \\
D1*LOG & & & \\
(JUB) & 678,7679 & 2,4289 & 0,0224 \\
\hline
\end{tabular}




\section{Jurnal Ekonomi Pembangunan, 17 (1), Juni 2016, 100-107}

Base on the result of regression, then the model is:

$$
\begin{aligned}
& J I I_{t}=9961,2945-74,7714 B \operatorname{IRATE} E_{t}-779,8585 \mathrm{LOG}(K U R S)_{t}+12,3473 I N F_{t} \\
&-134,3538 J U B_{t}-13818,4411 d 1_{t}+86,6611 d 1 B I R A T E_{t} \\
&+371,4370 d 1 L O G(K U R S)_{t}-14,3236 d 1 I N F_{t}+678,7679 d 1 L O G(J U B)_{t} \\
&+\mathrm{v}_{t}
\end{aligned}
$$

Based on the regression results showed that before the crisis in 2008, the rate of bi significant negative effect on the stock Jakarta Islamic Index, because prob.t value $0.0250<0.10$. If birate rose by one percent, the JII shares will decrease by 74.7714 percent. Results of this research was supported by Antonio et al (2013) which shows that birate have a significant negative effect on the JII. JII response to birate occurs due to changes in interest rates is information for investors related to investment returns. Investors found birate rise will cause an increase in bank deposit interest rate, so that investment in the form of bank deposits, the investor is considered to have minimum risk and more profitable than investing in the stock market. Negative influences interest rates on stock prices is also due to the behavior of investors tend to invest their funds in the form of investments other than stocks, so the price of the stock to go down (Hussin et al. 2012).

Exchange rate significant negative effect on the stock Jakarta Islamic Index, because prob.t value $0.0567<0.10$. If the exchange rate rose by 1 percent then JII stocks will fall by $779.8585 / 100$ $=7.7985$ percent. Result of this research was supported by Antonio et al (2013) Which shows that the exchange rate has a significant negative effect on the JII. The weakening rupiah trigger a rise in commodity prices, including production product supported this research. This resulted in increasing amount of production cost, and declining corporate profits. Corporate profits are down will affect the dividend policy, especially the cash dividend and this is the appeal of investors. Investor interest was down against the stocks can decrease the share price. Meanwhile inflation does not have a significant impact on Jakarta Islamic Index as 0.1691 prob.t value> 0.10 . Results of this study are supported by research conducted Fahrudin (2006), where inflation is not a significant effect on money supply JII. There is no significant effect on the stock Jakarta Islamic Index, because the value prob.t 0.6294> 0.10. This research was supported by Wijaya (2013), which shows that the money supply does not significantly influence the composite stock price.

Based on the regression results indicate birate coefficient of 86.6611 to $74.7714=11.8897$, while prob.t birate $(0.0320)$ is smaller than the significance level of 0.10 . It can be concluded that birate significant positive effect on JII. If birate rose one percent of the JII will increase by 11.8897 points. Results of research supported by research Jonathan (2013), which shows birate have a significant influence on the volume of LQ45. Means shares JII and LQ45 alike can be influenced by birate applied by the Central Bank in this case Bank Indonesia. In theory the results of this study are supported by the classical theory which states that if the interest rate increases, the amount of savings will exceed the entrepreneur wishes to invest.

Effect of exchange rate on the Jakarta Islamic Index

Based on the regression results table shows prob.t rate $(0.03766)$ is greater than the significance level of 0.10 . In conclusion, after the global monetary crisis, the exchange rate does not affect the JII. These results are supported by research conducted by Jonathan (2013), which showed that rupiah exchange rate against the dollar is not significantly affect the volume of LQ45. This is because Indonesia implement a free floating exchange rate policy in which the exchange rate was handed back to the market mechanism because since the crisis of 1997-1998, Indonesia's foreign exchange reserves no longer able to withstand the decline in the rupiah were 


\section{Jurnal Ekonomi Pembangunan, 17 (1), Juni 2016, 100-107}

so strong. Indonesia actually in the new order applying the fixed exchange rate system in a way if the rupiah weakens, then Bank Indonesia will buy the rupiah from the market through foreign exchange reserves to restore the value of the rupiah back on fix value.

Based on the regression results table shows inflation prob.t $(0.1956)$ is greater than the significance level of 0.10 , which means after the global financial crisis of 2008 , inflation has no significant effect on JII. The results showed the same results as did by Pasaribu et al (2013) that inflation does not significantly influence Indonesia. The sharia stock index was due to the role of Bank Indonesia in controlling inflation and birate good enough to push inflation higher. Moreover investors are also still feel comfortable and do not view inflation as a hindrance, because the alertness of Bank Indonesia monetary policy.

Effect of Money Supply to the Jakarta Islamic Index

Based on the table of regression results indicate that the coefficient of the amount of money in circulation amounted to 678.7679 and prob.t of 0.0224 is smaller than the significant level of 0.10 . The first conclusionis money supply has significant positive effect on JII. If the money supply increased by one million, the JII will increase by 6.7876 points. Result of this study was supported by research Pasaribu (2013) which shows that the money supply significant positive effect on Indonesian Islamic stock index. After the global financial crisis, the money supply has an influence on JII. Money supply steady growth in the amount of money will increase the society purchasing power so that improve the demand which have an impact on the stock in the capital market.

\section{Conclusion}

The results of multiple regression model estimation Chow test dummy variable approach as well as in previous economic intrepetasi some conclusions can be drawn:

First, the Cow test dummy approach showed differences in the effectiveness of monetary policy before and after the crisis.

Second, before the 2008 global financial crisis birate variable monetary policy and the exchange rate has a negative influence on the Jakarta Islamic Index. Influence is not in harmony shows the reality of our financial sector is still fragile.

Third, after the global financial crisis of 2008, partially bi variable rate and money supply significant positive effect on the Jakarta Islamic Index, while the exchange rate and inflation is not significant. Simultaneously, inflation, money supply, exchange rates and birate affect the Jakarta Islamic Index.

\section{Acknowledgement}

The author would like to thank the Indonesian Islamic university that has given support to this research. and other related parties that have provided the knowledge that this study there

\section{Reference}

Antonio, M. S., \& Fauzi, H. (2013). The Islamic Capital Market Volatility: A Comparative Study Between In Indonesia And Malaysia. In Buletin Ekonomi Moneter dan Perbankan. 391-416

Bank Indonesia. (2009). Outlook Ekonomi Indonesia 2009-2014, Edisi januari 2009. Access at 30 oktober 2015, From http://www. bi.go.id

Bank Indonesia. (2015). Jurnal Bank Indonesia. Access at 30 oktober 2015, From http://www. bi.go.id/moneter/data

Beik, I.S \& W. Wardhana. 2011. Te Relationship between Jakarta Islamic Index and Other Selected Markets: Evidence from Impulse Response Function. Majalah Ekonomi. Vol. XXI No.2.

Bursa Efek Indonesia. (2015). BEI monthly Statistic Report. Diambil tanggal 30 oktober 2015, dari situs http://www.idx.co.id/stock 


\section{Jurnal Ekonomi Pembangunan, 17 (1), Juni 2016, 100-107}

Sani G.A and Wahyudi I (2014 , Interdependence between Islamic capital market and money market: Evidence from Indonesia, Borsa Istanbul Review, Volume 14, Issue 1, March 2014, 2

Handayani. 2007. Pengaruh Tingkat Suku Bunga SBI, Nilai Kurs Dollar AS, dan Tingkat Inflasi terhadap Indeks Harga Saham Gabungan (IHSG) (Studi di Bursa Efek Jakarta), Tahun XVIX No. 1, Januari-Juni 2008. 55-67

Hussin, M.Y.M, et.al. 2012. Macroeconomic Variable and Malaysian Islamic Stock Market: A time Series Analysis. Journal of Business Studies Quarterly. Vol.3 No.4,.113.

Jonathan, Timotius Ibram. 2013. Analisa Pengaruh Inflasi, Suku Bunga dan Kurs Terhadap Volume Transaksi Pada Index LQ45. FINESTA: 1 (2) 141-144

Kristanti, F. T., \& Lathifah, N. T. (2013). Pengujian variabel makro ekonomi terhadap jakarta islamic index. Jurnal Keuangan Dan Perbankan, 17(1), 220-229.
Mulyani, N. (2014). Analisis Pengaruh Inflasi, Suku Bunga, Nilai Tukar Rupiah, Dan Produk Domestik Bruto Terhadap Jakarta Islamic Index. Jurnal Bisnis Dan Manajemen Eksekutif Vol. 1 No. 1, 2014, Artikel 10, 1(1).

Pasaribu, Rowland Bismark Fernando.,dan Mikail Firdaus. (2013). Analisis Pengaruh Variabel Makroekonomi terhadap Indeks Saham Syariah Indonesia. Jurnal Ekonomi dan Bisnis, Fakultas Ekonomi Universitas Gunadarma, Depok, Vol. 7, No. 2, Juni 2013.

Sihono, T. (2008). Krisis Finansial Amerika Serikat dan Perekonomian Indonesia. Jurnal Ekonomi \& Pendidikan, 5(2), 171-19

Wijaya, Renny, (2013). Pengaruh Fundamental Ekonomi Makro Terhadap Indeks Harga Saham Gabungan Pada Bursa Efek Indonesia Periode 2002-2011, Calyptra: Jurnal ilmiah mahasiswa universitas surabaya Vol 2 No 1, $1-5$ 